Buca Eğitim Fakültesi Dergisi, 2021, say1 52, s. 325-336

Araştırma Makalesi
The Journal of Buca Faculty of

Education, 2021, issue 52, p. 325-336

Research Article

\title{
Social Appearance Anxiety and Dimensions of Identity as Predictors of Friendship Quality among Adolescents
}

\section{Ergenlerde Arkadaşlık Kalitesinin Yordayıcısı Olarak Sosyal Görünüş Kaygısı ve Kimlik Boyutları}

\author{
Ümit MORSÜNBÜL ${ }^{1}$, Pinar KARABABAㄴ, Merve Fatma BAYSAL ${ }^{3}$, Ezgi ÖZKAN ${ }^{4}$
}

\begin{abstract}
${ }^{1}$ Prof. Dr., Rehberlik ve Psikolojik Danışmanlık Anabilim Dall, Eğitim Fakültesi, Aksaray Üniversitesi, Türkiye, morsünbülumit@gmail.com, (https://orcid.org/0000-0002-0750-5015)

${ }^{2}$ Sorumlu Yazar, Uzm. Psik. Dan., MEB, Türkiye, pcetiner_pdr@hotmail.com, (https://orcid.org/0000-0001-6769-2740)

${ }^{3}$ Yüksek Lisans Öğrencisi, Rehberlik ve Psikolojik Danışmanlık Anabilim Dalı, Eğitim Fakültesi, Aksaray Üniversitesi, Türkiye, mervebaysalmerve@gmail.com, (https://orcid.org/0000-00020935-0010)

${ }^{4}$ Yüksek Lisans Öğrencisi, Rehberlik ve Psikolojik Danışmanlık Anabilim Dal, Eğitim Fakültesi, Aksaray Üniversitesi, Türkiye, ezgi.ozkannn@hotmail.com, (https://orcid.org/0000-0002-63545353)
\end{abstract}

Geliş Tarihi: 24.03.2021

Kabul Tarihi: 07.12.2021

\begin{abstract}
The purpose of the current study was to investigate the relationships between social appearance anxiety, dimensions of identity, and friendship quality among adolescents. The sample of the research consisted of 285 adolescents (163 female and 122 male) attending Anatolian High School. The current study was conducted by correlational research design. The instruments of the study were The Utrecht-Management of Identity Commitments Scale (U-MICS), The Friendship Quality Scale, and The Social Appearance Anxiety Scale. The analyses of the study were carried out by SPSS 23.0 program. The study finding showed that friendship quality was negatively associated with social appearance anxiety, and positively associated with commitment and in-depth exploration. Also, the results showed that commitment and social appearance anxiety significantly predicted the level of friendship quality. The theoretical and practical implications of these findings were discussed.
\end{abstract}

Keywords: Friendship quality, social appearance anxiety, dimensions of identity, adolescence.

ÖZ

Bu çalışmanın amacı ergenlerde arkadaşlık kalitesi, sosyal görünüş kaygısı ve kimlik gelişimi arasındaki ilişkileri incelemektir. Araştırmanın katılımcı grubunu bir anadolu lisesine devam 285 (163 kadın ve 122 erkek) ergen oluşturmaktadır. Araştırma ilişkisel tarama modeli ışı̆ğında yürütülmüsşür. Araştırmada kullanılan ölçme araçları Arkadaşlık Kalitesi Ölçeği, Utrecht Kimlik Bağlanma Ölçeği ve Sosyal Görünüş Kaygısı Ölçeğidir. Araştırmanın analizleri SPSS 23.0 programı aracılığıyla yürütülmüştür. Araştırma bulgusu arkadaşlık kalitesinin sosyal görünüş kaygısı ile negatif, bağlanma yapma ve derinlemesine keşif değişkenleri ile ise pozitif olarak iliş̧i içinde olduğunu göstermiştir. Ayrıca sonuçlar, kimlik boyutlarından bağlanma yapma ile sosyal görünüş kaygısının arkadaşlık kalitesi düzeyini anlamlı olarak yordadığını göstermiştir. Mevcut araştırma bulgularının teorik ve pratik sonuçları tartışılmışıır

Anahtar Kalimeler: Arkadaşlık kalitesi, sosyal görünüş kaygısı, kimlik boyutları, ergenlik. 


\section{INTRODUCTION}

The friendship that is voluntary relationships with an agemate serves many important functions such as facilitating interpersonal skills and social adjustment, providing emotional support, enhancing well-being, and developing social skills throughout lifespan. The dynamics of friendship relationships relatively vary with the developmental periods. The concept of friendship that is associated with the game during childhood becomes even more important in adolescence (Katmer, 2018). The concept of friendship that comes into prominence in adolescence has important functions for an individual's cognitive, emotional, and social development. Unlike childhood, the individual wants to build new relationships in adolescence. Friendship is one of the most important issues of adolescence period and has great importance in his/her personality development, maturation and socialization, the sexual identity development, sense of belonging to a group, and the development of sharing and responsibility senses (Dinçer, 2008; Kornienko, Santos, Martin, \& Granger, 2016; Rubin, Dwyer, Booth LaForce, Kim, Burgess , \& Rose Krasnor, 2004; Vitaro, Boivin, \& Bukowski, 2009). While friendship relationships contribute to individuals learn and experience new behaviors and socialize, they also decrease adolescent's loneliness levels and increase his/her social network (Çevik, 2007; Lodder, Scholte, Goossens, \& Verhagen, 2017; Schwartz-Mette, Shankman, Dueweke, Borowski, \& Rose, 2020).

Considering that one of the salient developmental tasks confronting adolescents is establishing friendship and maintaining it (Steinberg, 1990), it is not surprising that this relationship contributes to adolescents' development. Friendship is defined as the relationship between two or more persons who support, protect, and relieve each other against stressful events (Kimmel \& Weinner, 1995). According to Köknel (1997), friendship is described as the smallest social unit in which collective behavior patterns and attitudes are shared, and new behavior patterns and attitudes are developed. On the other hand, friendship quality refers to the quality and functionality of these friendship relationships rather than of quantity of individuals' friendships (Akın, 2015). Friendship quality directly influences many points in the social development of individuals especially self-esteem and social adaptation (Berndt, 2002). According to Asher and Parker (1993), the level of friendship quality demonstrates how much individuals adopt their friendships.

In adolescence, it is very important for the individual to be accepted by persons around him/her and to be evaluated positively by a group of friends and one of the most important developmental properties of this period is that the adolescent individual gives particular importance to his/her appearance. In this period, social appearance anxiety in tandem with the rapid physical changes is more intensely experienced by individuals (Özcan, Subaş1, Budak, Çelik, Gürel, \& Yıldız, 2013). Social appearance anxiety is undoubtedly developed by feedback from the environment (Doğan, 2011). Social appearance anxiety is that the individual has a negative body image regarding his/her physical appearance and body (Doğan, 2011). Hart, Flora, Palyo, Fresco, Holle, \& Heimberg. (2008) suggest that social appearance anxiety involves not only physical properties such as height and weight but also an individual's eye color, skin color, facade construction, and smile. The deficiency that may occur in these characteristics of an individual leads to the development of beliefs such as humiliation, rejection, and exclusion (Doğan, 2010).

The current study also focused on identity apart from social appearance. Social appearance has become increasingly central to defining identity in the modern age (Negrin, 2008). Identity is an important concept that develops in adolescence and influences other periods of life (Atak, 2011), just like social appearance. During adolescence, a stable self-concept emerges in which one develops a subjective view of one's identity that recognizes that one is different and autonomous from others (Erikson, 1968). In the studies conducted on what the 
concept of identity is, it is seen that identity is briefly considered as the answer to the question "who am I" (Morsünbül, 2010).

The word identity is described as the organized set of images and the sense of self, which express who we really are and what we want (Erikson, 1994). According to Erikson (1968), identity is an important task that should be achieved in adolescence. Erikson (1968) evaluates the formation of identity as a process in which an individual makes trials in three areas: love, work, and worldview. According to Erikson, identity is the sense of accepting his/her body, knowing where himself/herself is going, and knowing that people who are important to him/her accept him/her. Achieving identity is the culmination of earlier developmental tasks in the life cycle and a building block for a later developmental task (Erikson, 1994). The identity concept is considered and interpreted in various ways. Identity sometimes corresponds to one's global identity, an overall sense of self or sense of being. On the other hand, identity may be also defined in a more specific manner to highlight either particular dimensions of identity or the core essence of self.

Considering the literature, since identity is a concept that includes cognitive, physical, and social factors, it has been seen that researchers cannot reach a consensus on identity. According to Marcia (1993), identity is a dynamic construct which an individual's beliefs, impulsions, and personal background constitute. Marcia (1993) asserts that the sense of identity can be measured and revealed identity statuses according to attachment and depression criteria (Atak, 2011). These identity statuses were distinguished into four groups: identity diffusion, foreclosure, identity achievement, and moratorium. The statuses were developed to define an individual's ego states. These statuses of identity were not evaluated as stereotyped by the researchers. That is, there may be a transition from one status to another (Marcia, 1993). It is expected that individuals develop a consistent and constant identity in both adolescence and emerging adult periods contributes to more healthful entry into adulthood and to more comfortably achieve their developmental tasks (Morsünbül \& Çok, 2013).

The fact that an individual has a healthy identity development process during adolescence provides him/her to more comfortably achieve tasks that other life periods require (Erikson, 1968; Morsünbül \& Çok, 2013). By expanding Marcia's (1980) Identity Status Model, the Identity Development Model with three-dimensional focusing on three basic processes in identity development was formed. First, commitment refers to firm choices made with regard to various developmental domains; second, in-depth exploration refers individuals to take an active role in their existing commitments, collect additional information, and gain insight into them; third, reconsideration of commitment is described as the expression of various options for individuals' commitment processes (Crocetti, Schwartz, Fermani, \& Meeus, 2010). While the individuals who positively evaluate themselves as physical during adolescence are more successful in interpersonal relationships, the individuals who are not satisfied with themselves may be in unsafe and restless feelings in many periods of their lifespan (Demirer, 2005; Ergür 1996; Lyu \& Gill, 2012). That is, individuals' thoughts about how they are perceived by others affect friendship relationships. Individuals with good social skills are also more compatible with friendship relationships than weak ones. Friend support encourages adolescents, reinforces them, and increases their self-esteem in this period (Tian, Liu, Huang, \& Huebner, 2013). At the same time, friendship in this period has an impact on adolescent's many aspects such as his/her formation of values, choice of profession, and the development of identity (Dögücü 2004; Wang $\& \mathrm{Gu}, 2019$ ). For example, Kindschi et al. (2019) found that adolescents' value systems evolve in a continuous cycle of internal validation through the selection and enactment of goals-thereby experiencing both congruence and conflicts-and external validation through social comparison among their friends.

The current study has importance for several reasons. Firstly, adolescence, as stated previously, is a developmental period when friendship becomes increasingly important. Friendship is a source of support and intimacy and thus plays a critical role in adolescents' 
holistic development (Bukowski, Bagwell, Castellanos, \& Persram, 2020). Therefore, it is important to examine the mechanisms underlying friendship quality using a sample of adolescents. The current findings may help school mental health professionals in developing prevention and intervention programs focusing on promoting adolescents' friendship quality. Also, this study focused on social appearance anxiety ad identity as the variables that have the potential role in predicting friendship quality. Both constructs have critical importance to adolescent development. Lastly, when considering the literature, while there are studies demonstrating the significant relationships between both friendship relationships and social appearance anxiety (Çetinkaya, Gülaçtı, \& Çiftçi, 2019) and identity and friendship quality (Seffrin, Giordano, Manning, \& Longmore, 2009; Weisz \& Wood, 2000), the study indicating the relationships among individuals' identity development, social appearance anxiety, and friendship quality in adolescence period was not found. Moreover, the majority of studies focusing on the predictors of friendship quality were conducted in Chinese and Western cultures, and little is known about it in Turkish culture. It is valuable to know that the current study fills the gap in the literature by indicating the relationships among these variables. In light of this information, the purpose of the current research was to examine whether social appearance anxiety and the dimensions of identity significantly predicted the friendship quality level of adolescents.

\section{METHOD}

\subsection{The Sample of The Study}

The present study was carried out utilizing a correlational research model. The study sample consisted of 285 (163 female and122 male) high school students participating in the study voluntarily and attending Atatürk Anatolian High School in Niğde. Of the participants, 90 $(31.6 \%)$ were 9th graders, $93(32.6 \%)$ were 10th graders, $47(16.5 \%)$ were 11th graders, and 55 $(19.3 \%)$ were 12 th graders. The participants' age mean was $15.6(\mathrm{SD}=1.27)$.

\subsection{The Instruments}

\subsubsection{The Friendship Quality Scale}

The Friendship Quality Scale developed by Thien, Razak, and Jamil (2012) and adapted to Turkish culture by Akın, Karduz, and Akın (2014) was implemented in the study to collect the study data about participants' perceptions of friendship quality. The scale consists of 21 items and 4 subdimensions. Ratings are made on a six-point scale from high strongly disagree (1) to high strongly agree (6). The scale yields to both each subdimension and total friendship quality score. The higher scores show a higher friendship quality level. The subdimensions of the scale: safety (eight items, the sample item; "My friends never lie to me."), closeness (six items, the sample item; "I always joke with my friends."), acceptance (four items, the sample item; "My friends treat me well."), and help (three items, the sample item; "My friends help me to solve problems."). In the present study, Cronbach's alpha coefficient of the scale was calculated as .89 for the overall scale.

\subsubsection{The Social Appearance Anxiety Scale}

The Social Appearance Anxiety Scale developed by Hart et al. (2008) and adapted to Turkish culture by Doğan (2010) was used in the current study to collect the data about participants' social appearance anxiety levels. The scale consists of 16 items and one dimension rates on a 5-point Likert scale (from ' $1=$ not at all' to ' $5=$ extremely'). A sample item of the scale is "I feel nervous when having my picture taken." The total score ranges from 16 to 80 . The higher scores show higher social appearance anxiety levels. In this study, Cronbach's alpha coefficient was calculated as .91. 


\subsubsection{The Utrecht-Management of Identity Commitments Scale (U-MICS)}

The Utrecht-Management of Identity Commitments Scale, which was developed by Crocetti, Rubini, and Meeus (2008) and adapted to Turkish culture by Morsunbul, Crocetti, Cok, and Meeus (2014), was used to determine students' identity development processes. The scale which is a 5-point Likert scale (from ' $1=$ completely untrue' to ' $5=$ completely true') consists of 26 items and three subdimensions. The sample items of the scale are "I often think it would be better to try to find a different education." for reconsideration of commitment, "I try to find out a lot about my education" for in-depth exploration, and "My education gives me security in life." for commitment. The reliability coefficients ranged between .79 and .87 in the Turkish adaptation study. The subdimensions related to the friend domain of the scale were used in this study. The Cronbach's alpha coefficients regarding the subdimensions were calculated as .85 for reconsideration of commitment, .76 for in-depth exploration, and .87 for commitment.

\subsection{Procedure}

The data of the study were obtained from high school students participating in the research voluntarily. The necessary permissions were firstly obtained from the school administration to conduct the data collection. Before the data collection, the students were informed about the study's aim and process. The research instruments were administered to the participants by the researcher in their respective classrooms during school hours. The participants filled out the surveys in approximately 10 minutes. The SPSS program was used to analyze the data. Pearson Correlation coefficient was conducted to test the relationships among social appearance anxiety, friendship quality, and development of identity, and the multiple regression analysis was used to investigate whether the independent variables (social appearance anxiety and the dimensions of identity) predicted the dependent variable (friendship quality).

\section{Data Analysis}

IBM Statistical Package Social Science (SPSS) version 23.0 was used to calculate descriptive statistics and conduct correlation and regression analyses in the current study. Concerning the descriptive statistics, the mean and standard deviation values of the studied variables were determined. Then, the correlation coefficients between the current variables were found by the Pearson Correlation analysis. Lastly, the multiple regression analysis was conducted to determine the predicting roles of social appearance anxiety and identity in friendship quality. Before the regression analysis, pre-condition values including skewness, kurtosis, VIF, and tolerance coefficients were calculated.

\section{RESULTS}

The results of descriptive statistics and correlations were firstly given. Then, the results regarding the regression analysis were presented.

\subsection{The Correlations between the Variables}

Mean, standard deviation, and correlation values regarding the variables were presented in Table 1.

Table 1. The Correlation Coefficients Regarding The Variables

\begin{tabular}{lllllll}
\hline Variable & Mean & s.d. & 1 & 2 & 3 & 4 \\
\hline 1. Friendship quality & 84.08 & 18.92 & 1 & & & \\
\hline 2. Social appearance anxiety & 31.96 & 11.57 & $-.20^{* *}$ & 1 & & \\
\hline 3. Commitment & 18.45 & 4.25 & $.39^{* *}$ & -.00 & 1 & \\
\hline 4. In-depth exploration & 14.67 & 4.11 & $.24^{* *}$ & .04 & $.44^{* *}$ & 1 \\
\hline 5. Reconsideration of commitment & 7.58 & 3.47 & .09 & .04 & -.04 & $.22^{* *}$ \\
\hline$* \mathrm{p}<.05, * * \mathrm{p}<.01$ & & & & & &
\end{tabular}


When considering the analysis findings in Table 1; the findings indicated that friendship quality was negatively associated with social appearance anxiety $(\mathrm{r}=-.20, \mathrm{p}<.01)$, and positively associated with commitment $(\mathrm{r}=.39, \mathrm{p}<.01)$ and in-depth exploration $(\mathrm{r}=.24, \mathrm{p}<.01)$. Also, there is no relationship between friendship quality and reconsideration of commitment $(r=.09, p>.05)$.

\subsection{The Regression Analysis}

The multiple regression analysis was conducted to determine the variables predicting friendship quality. To determine whether the data fit in with the multiple regression analysis, the values of skewness and kurtosis were examined and it was seen that these values were between +1.5 and -1.5 . Therefore, it can be said that the data have a normal distribution. To determine if the multicollinearity was between the independent variables, the bilateral relationships between the variables were examined. It was concluded that there is no .80 correlation and higher between the variables. Also, the values of VIF (ranging from 1.00 to 1.33) and Tolerance (ranging from .74 to .99 ) were examined to determine a multicollinearity problem, it was found that there is no multicollinearity.

Table 2. The Results of Regression Analysis for Predicting Friendship Quality

\begin{tabular}{|c|c|c|c|c|c|c|}
\hline Model & $\begin{array}{l}\text { Unstanc } \\
\text { coeffici }\end{array}$ & & $\begin{array}{l}\text { Standardized } \\
\text { coefficients }\end{array}$ & & & \\
\hline & $\mathrm{B}$ & Std. Error & Beta & $\mathrm{t}$ & $\mathrm{R}$ & $\mathrm{R}^{2}$ \\
\hline Constant & 56.392 & 5.885 & & 9.583 & \multirow{5}{*}{.45} & \multirow{5}{*}{.20} \\
\hline $\begin{array}{l}\text { Social appearance } \\
\text { anxiety }\end{array}$ & -.33 & .09 & -.20 & $-3.770 * *$ & & \\
\hline Commitment & 1.604 & .27 & .36 & $5.997 * *$ & & \\
\hline In-depth exploration & .31 & .28 & .07 & 1.087 & & \\
\hline $\begin{array}{l}\text { Reconsideration of } \\
\text { commitment }\end{array}$ & .54 & .30 & .10 & 1.777 & & \\
\hline
\end{tabular}

$* p<.05, * * p<.01$

The results of the regression analysis that was conducted to determine if social appearance anxiety and dimensions of identity predicted friendship quality were presented in Table 2 . When considering the results, it was seen that the independent variables significantly predicted friendship quality $(\mathrm{R}=.45, \mathrm{R} 2=.20, \mathrm{~F}=17.956, \mathrm{p}<.01)$. According to the $\mathrm{t}$-test results relating to the independent variables, the variables of social appearance anxiety $(\beta=-.20, p<.01)$ and commitment $(\beta=.36, \mathrm{p}<.01)$ significantly predicted friendship quality.

\section{DISCUSSION}

In this study, it was examined whether social appearance anxiety and the dimensions of identity significantly would predict the friendship quality level of adolescents. The study finding showed that friendship quality was negatively associated with social appearance anxiety, and positively associated with commitment and in-depth exploration. Also, the results showed that commitment and social appearance anxiety significantly predicted the level of friendship quality.

Social appearance is important during adolescence. In this period, individuals are more sensitive to the evaluations about their body and they worry about being negatively evaluated (Doğan, 2011; Jarman, Marques, McLean, Slater, \& Paxton, 2021; Paddock \& Bell, 2021). It was found that the individuals who are satisfied with their social appearance have more characteristics such as self-esteem, tolerance, friendship satisfaction (Feragen, Kvalem, Rumsey, \& Borge, 2010; Seki \& Dilmaç, 2015). When an individual positively evaluates themselves as physical, she/he is more successful in interpersonal relationships, on the other hand, the individuals who negatively evaluate and are not satisfied with themselves have unsafe and restless feelings constantly. For example, a study conducted by Lyu \& Gill (2012) on adolescents indicated that the positive 
perception of physical competence and body image were significantly linked to perceived peer acceptance for them. Prior studies conducted on friendship quality indicated that positive characteristics such as loyalty, subjective well-being, self-esteem, and extraversion contribute to friendship relationships positively (Liem, Lustig, \& Dillon, 2010; Thomas \& Daubman, 2001). Individuals with negative body image frequently examine their bodies and find the defects related to their bodies. When these individuals think that their bodies will be also examined in interpersonal relations, they feel anxiety and shame and may detach themselves from others. In the study, Benenson and Benarroch (1998) examined the factors which were thought to affect female-male friendship, it was concluded that boys cared more about the physical appearance in their friendships and girls gave more importance to attractiveness in their close friendships. In a similar study conducted by Oktay and Şahin (2010), the association between self-esteem and body image among female adolescents was examined. The results demonstrated that body image was significantly related to self-esteem. Seki and Dilmaç's (2015) study examining the relationship between subjective well-being and social appearance anxiety among adolescents, found that subjective well-being was negatively related to social appearance anxiety. The self-esteem of an individual who has negative body image decreases, as a result, he/she can isolate himself/herself from the social environment. These results in the literature support the present findings.

The second study finding showed that commitment as an identity dimension was the most important and significant predictor of friendship quality. Commitment refers to individuals make their choices regarding different developmental domains permanent (Kroger, 2006; Morsünbül \& Uçar, 2017). The individual who makes his/her choices permanent develops a healthier sense of identity. Thus, the individual has a higher level of self-esteem and feels more energetic. Because he/she doesn't regard himself/herself and his/her environment as a threat, his/her friendship quality increases (Ryan \& Frederick, 1997). Consistent with the current finding, Weisz and Wood's (2000) study found that social identities are a distinct type of social support with consequences for interpersonal relationships. According to Erikson (1968), close relationships made with friends in adolescence are very important for identity development. Laible (2007) conducted a study examining attachment to parents and friends, and socio-emotional skills, it was found that secure attachment to friends positively influenced socio-emotional skills. In light of these explanations, a right friend choice, an adolescent's stability regarding this choice, and identity development positively influence friendship quality.

The current findings showed that commitment and social appearance anxiety significantly predicted the level of friendship quality among adolescents. The present study has some limitations. It is important to consider these results in light of the limitations. First, The relationships among the variables of social appearance anxiety, identity, and friendship quality were presented as correlational. Therefore, the causal relationships cannot be inferred from the current study. Future studies can focus on experimental methods. Second, another limitation is that the data are limited to high school students in Niğde city. In this context, future studies that will be conducted on adolescents in different cultures are important in terms of generalization and reliability of the results. Third, because the sample of the study consists of individuals whose ages range between 14 and 18, it is not possible to generalize the findings to other age groups. Carrying out similar studies among other age groups will contribute to having a comprehensive knowledge of the subject. Four, the current study is limited to commitment, in-depth exploration, and reconsideration of commitment identity sub-dimensions. Therefore, to more comprehensively explore the effect of identity development on friendship quality, there is a need for more studies on the different dimensions of identity development.

Notwithstanding, the current study has some strengths. The current study, to our knowledge, provides some of the first evidence of the relationships among social appearance anxiety, identity, and friendship quality. For mental health specialists, considering social appearance anxiety and identity development can be part of interventions to improve adolescents' friendship quality levels. Also, class teachers, school counselors, and specialists can make 
attempts on promoting adolescents to have a positive social appearance perception and identity development.

\section{REFERENCES}

Akın, A., \& Akın, Ü. (2015). Friendship quality and subjective happiness: The Mediator role of subjective vitality. Education and Science, 177, 233-242.

Asher, S. R., \& Parker, J. G. (1993). Friendship and friendship quality in middle childhood: Links with peer group acceptance and feelings of loneliness and social dissatisfaction. Developmental Psychology, 29, 611-621.

Atak, H. (2011). Identity development and identity formation: A theoretical assessment. Current Approaches in Psychiatry, 3(1), 163-213.

Erikson, E. H. (1968). Identity youth and crisis. New York: WW Norton.

Berndt, J. T. (2002). Friendship quality and social development. Current Directions in Psychological Science, 11(1), 7-10.

Bukowski, W. M., Bagwell, C., Castellanos, M., \& Persram, R. J. (2020). Friendship in adolescence. In S. Hupp \& J. Jewell (Eds). The encyclopedia of child and adolescent development (pp. 1-11). John Wiley \& Sons, Inc.

Crocetti, E., Rubini, M., \& Meeus, W. (2008). Capturing the dynamics of identity formation in various ethnic groups: development and validation of a three dimensional model. Journal of Adolescence, 31(2), 207-222.

Çetinkaya, B., Gülaçtı, F., \& Çiftci, Z. (2019). Lise öğrencilerinin sosyal görünüş kayg1 düzeylerinin bazı değişkenlere göre incelenmesi. OPUS Uluslararası Toplum Araştırmaları Dergisi, 10(17), 904-922.

Çevik, G. B. (2007). An investigation of third graders' friendship characteristics and their selfesteem regarding of some variable at secondary schools. (Unpublished Master's Thesis). Cukurova University, Adana.

Demirer, Y. (2005). Beden algısı ve ruh sağlığı. Retrieved from http://www.acilservis.pro/bedenalgisi-ve-ruh-sagligi.

Dinçer, B. (2008). A study on perceptions about parental attitudes and friendship relations of adolescent attending to second grade of high school in low and high socio-economic level. (Unpublished Master's Thesis). Ankara University, Ankara.

Doğan, T. (2010). Adaptation of The Social Appearance Anxiety Scale (SAAS) to Turkish: A validity and reliability study. Journal of Hacettepe University Education Faculty, 39(39), 151-159.

Doğan, T. (2011). An investigation of the psychometric properties of the social appearance anxiety scale in an adolescent sample. Elementary Education Online, 10(1), 12-19.

Döğücü, F. (2004). The study of the friend relations of the tenages at the various high school in the town of Tosya. Unpublished master's thesis, Gazi University, Ankara.

Erikson, E. H. (1968). Identity: Youth and crisis. New York: Norton.

Erikson, E. H. (1994). Identity and the life cycle. WW Norton \& Company.

Ergür, E. (1996). Üniversite ögrrencilerinde beden-benlik algısı ve ruh să̆ğğ arasındaki ilişki. (Unpublished master's thesis). Ege University, İzmir. 
Feragen, K. B., Kvalem, I. L., Rumsey, N., \& Borge, A. I. (2010). Adolescents with and without a facial difference: The role of friendships and social acceptance in perceptions of appearance and emotional resilience. Body Image, 7(4), 271-279.

Hart, T. A., Flora, D. B., Palyo, S. A., Fresco, D. M., Holle, C., \& Heimberg, R. G. (2008). Development and examination of the social appearance anxiety scale. Assessment, 15(1), 48-59.

Jarman, H. K., Marques, M. D., McLean, S. A., Slater, A., \& Paxton, S. J. (2021). Social media, body satisfaction and well-being among adolescents: A mediation model of appearanceideal internalization and comparison. Body Image, 36, 139-148.

Kalafat, A. (2019). Examination of predictive relationship between identity development, achievement goal orientation and cognitive complexity in adolescents. (Unpublished Master's thesis). İstanbul Sabahattin Zaim University, İstanbul.

Kara, A. (2016). Sosyal görünüş kaygısı ile utangaçlık arasındaki ilişkilerin incelenmesi. Birey ve Toplum, 6(1), 95-106.

Katmer, A. (2018). An investigation of friendship quality, attachment to friends and perceived social support from friends as predictors of loneliness. Unpublished master's thesis, Gaziantep University, Gaziantep.

Kimmel, D. C., \& Weinner, I. B. (1995). Adolescence: A developmental transition. John Wiley $\&$ Sons Incorporated.

Kindschi, M., Cieciuch, J., Davidov, E., Ehlert, A., Rauhut, H., Tessone, C. J., \& Algesheimer, R. (2019). Values in adolescent friendship networks. Network Science, 7(4), 498-522.

Kornienko, O., Santos, C. E., Martin, C. L., \& Granger, K. L. (2016). Peer influence on gender identity development in adolescence. Developmental Psychology, 52(10), 1578-1592.

Köknel, Ö. (1997). İnsanı anlamak (6. ed.). İstanbul: Altın Kitaplar Yayınevi.

Kroger, J. (2006). Identity development: Adolescence through adulthood. Sage publications.

Laible, D. (2007). Attachment with parents and peers in late adolescence: Links with emotional competence and social behavior. Personality and Individual Differences, 43(5), 1185-1197.

Liem, J. H., Lustig, K., \& Dillon, C. (2010). Depressive symptoms and life satisfaction among emerging adults: A comparison of high school dropouts and graduates. Journal of Adult Development, 17(1), 33-44.

Lodder, G. M. A., Scholte, R. H. J., Goossens, L., \& Verhagen, M. (2017). Loneliness iin early adolescence: Friendship quantity, friendship quality, and dyadic process. Journal of Clinical Child \& Adolescent Psychology, 46(5), 709-720.

Lyu, M., \& Gill, D. (2012). Perceived physical competence and body image as predictors of perceived peer acceptance in adolescents. Asian Journal of Social Psychology, 15(1), $37-$ 48.

Marcia, J. (1993). The relational roots of identity. In J. Kroger (Ed.), Discussions on ego identity (pp. 34-65). NJ, England: Lawrence Erlbaum Associates.

Morsünbül Ü. (2010). Ergenlikte kimlik gelişimini açıklayan yaklaşımlar/modeller: Ergen ruh sağlığı açısından sonuçları. Çocuk ve Gençlik Ruh Sağllğı Dergisi, 17, 105-111.

Morsunbul, U., Crocetti, E., Cok, F., \& Meeus, W. (2014). Brief report: The Utrecht-Management of Identity Commitments Scale (U-MICS): Gender and age measurement invariance and convergent validity of the Turkish version. Journal of Adolescence, 37(6), 799-805. 
Negrin, L. (2008). Appearance and identity. In Appearance and identity (pp. 9-32). Palgrave Macmillan, New York.

Oktan, V., \& Şahin, M. (2010). Examination of the relationship between the body image and selfesteem of female adolescents. Journal of Human Sciences, 7(2), 543-556.

Özcan, H., Subaşı, B., Budak, B., Çelik, M., Gürel, Ş. C., \& Yıldız, M. (2013). Ergenlik ve genç yetişkinlik dönemindeki kadınlarda benlik saygısı, sosyal görünüş kaygısı, depresyon ve anksiyete ilişkisi. Journal of Mood Disorders, 3(3), 107- 113.

Ökten, Ü. (2019). The mediator role of self-esteem in the relationship between social appearance anxiety and shyness in high school students: Şlrnak province sample. (Unpublished Master's Thesis). Üsküdar University, İstanbul.

Paddock, D. L., \& Bell, B. T. (2021). "It's better saying I look fat instead of saying you look fat": A Qualitative Study of UK Adolescents' Understanding of Appearance-Related Interactions on Social Media. Journal of Adolescent Research, 07435584211034875.

Rubin, K. H., Dwyer, K. M., Booth-LaForce, C., Kim, A. H., Burgess, K. B., \& Rose-Krasnor, L. (2004). Attachment, friendship, and psychosocial functioning in early adolescence. Journal of Early Adolescence, 24(4), 326-356.

Ryan, R. M., \& Frederick, C. (1997). On energy, personality and health: Subjective vitality as a dynamic reflection of well-being. Journal of Personality, 65, 529-565.

Saki, E. (2019). The role of perfectionistic self presentation in the relation of perfectionism and friendship quality. (Unpublished Master's Thesis). Dokuz Eylül University, İzmir.

Schwartz-Mette, R. A., Shankman, J., Dueweke, A. R., Borowski, S., \& Rose, A. J. (2020). Relations of friendship experiences with depressive symptoms and loneliness in childhood and adolescence: A meta-analytic review. Psychological Bulletin, 146(8), 664-700.

Seffrin, P. M., Giordano, P. C., Manning, W. D., \& Longmore, M. A. (2009). The influence of dating relationships on friendship networks, identity development, and delinquency. Justice Quarterly, 26(2), 238-267.

Seki, T., \& Dilmaç, B. (2015). Predictor relationships between the values the adolescents have and their levels of subjective well-being and social appearance anxiety: A model proposal. Education and Science, 40(179), 57-67.

Steinberg, L. (1990). Interdependence in the family: Autonomy, conflict, and harmony in the parent-adolescent relationship. In S. S. Feldman \& G. R. Elliot (Eds.), At the threshold: The developing adolescent (pp. 255-276). Cambridge, MA: Harvard University Press.

Tian, L., Liu, B., Huang, S., \& Huebner, E. S. (2013). Perceived social support and school wellbeing among Chinese early and middle adolescents: The mediational role of selfesteem. Social Indicators Research, 113(3), 991-1008.

Thomas, J. J., \& Daubman, K. A. (2001). The relationship between friendship quality and selfesteem in adolescent girls and boys. Sex Roles, 45(1), 53-65.

Thien, L. M., Razak, N. A., \& Jamil, H. (2012). Friendship Quality Scale: Conceptualization, development and validation. Australian Association for Research in Education (NJ1), 114.

Vitaro, F., Boivin, M., \& Bukowski, W. M. (2009). The role of friendship in child and adolescent psychosocial development. In K. H. Rubin, W. M. Bukowski, \& B. Laursen (Eds.), Handbook of peer interactions, relationships, and groups (pp. 568-585). The Guilford Press. 
Wang, C., \& Gu, X. (2019). Influence of adolescents' peer relationships and social media on academic identity. Asia Pacific Journal of Education, 39(3), 357-371.

Weisz, C., \& Wood, L. F. (2000). Social identities and friendships: A longitudinal study of support for social identities. Journal Of Social Behavior And Personality, 15(4), 441-458.

\section{GENIŞLETILMIŞ ÖZET}

\section{Giriş}

Çocukluk çağında oyunla ilişkilendirilen arkadaşlık kavramı ergenlik döneminde giderek önemini arttırmaktadır (Katmer, 2018). Ergenlik döneminde ön plana çıkan arkadaşlık kavramı, bireyin zihinsel, duygusal, ruhsal ve sosyal gelişimi için önemli işleve sahiptir. Ergenlik döneminde arkadaş ilişkileri bireyin sosyalleşmesine, yeni davranışlar öğrenmesine ve deneyimlemesine katkıda bulunurken aynı zamanda ergenin yalnızlık seviyesini düşürmekte ve sosyal destek algılarını artırmaktadır (Çevik 2007). Arkadaşlık kalitesi ise bireyin arkadaşlıklarının niceliğinden çok, bu arkadaşlık ilişkilerindeki kalite ve işlevselliğidir (Akın, 2015). Arkadaşlık kalitesi, bireylerin özgüvenleri ve sosyal uyumları başta olmak üzere sosyal gelişiminde birçok noktayı doğrudan etkilemektedir (Berndt, 2002). Ergenlik döneminde birey için çevresinden kabul görmek, arkadaş grubunca olumlu değerlendirilmek oldukça önemlidir ve bu dönemin önemli gelişimsel özellerinden biri de ergenlik döneminde bulunan bireyin görünüşüne aşırı önem vermesidir. Bu dönemde bedensel değişimlerin çok hızlı olmasıyla beraber sosyal görünüş kaygısı daha fazla yaşanmaktadır (Özcan vd., 2013). Sosyal görünüş kaygısı şüphesiz çevreden alınan geribildirimlerden beslenmektedir (Doğan, 2011). Sosyal görünüş kaygısı bireyin fiziksel görünümü ve bedeniyle ilgili olumsuz beden imgesine sahip olmasıdır (Doğan, 2010). Mevcut araştırmadaki diğer bir bağımsız değişken olan kimlik, ergenlikte başlayan, hayatın diğer dönemlerini de etkileyen önemli bir kavramdır (Atak, 2011). Kimlik kavramının ne olduğu üzerine yapılan araştırmalarda kimliğin kısaca "Ben kimim?" sorusuna verilen cevap olarak değerlendirildiği görülmektedir (Morsünbül, 2010). Bireyin ergenlikte sağlıklı bir kimlik geliştirme süreci geçirmesi diğer yaşam dönemlerinin gerektirdiği ödevleri daha rahat tamamlamasında kolaylık sağlayacaktır (Erikson, 1968; Morsünbül ve Çok, 2013). Marcia'nın (1980) Kimlik Statüleri Modeli genişletilerek, kimlik gelişiminde üç temel sürece odaklanan Üç boyutlu Kimlik Gelişimi Modeli oluşturulmuştur. İlk olarak bağlanma yapma; çeşitli gelişim alanlarına yönelik geçekleştirilen seçimlerin netleştirilmesi, ikinci süreç olarak derinlemesine keşif; bireylerin sahip olduğu bağlanmalar üzerinde aktif olarak rol alması ve bu süreç hakkında yeni bilgi toplaması ve fikir sahibi olması, üçüncü süreç ise bağlanmanın yeniden gözden geçirilmesi; bireylerin sahip olduğu bağlanma süreçlerine ilişkin çeşitli seçeneklerin ifade edilmesidir (Crocetti vd., 2010). Literatür incelendiğinde arkadaşlık ilişkileri ile sosyal görünüş kaygısı arasında anlamlı ilişkinin olduğuna dair çalışmalar varken (Çetinkaya vd., 2019), ergenlik döneminde bireylerin kimlik gelişimi, sosyal görünüş kaygısı ve arkadaşlık kalitesi arasındaki ilişkiyi vurgulayan bir araştırma bulgusuna rastlanmamıştır. Mevcut araştırma bu değişkenler arası ilişkileri tespit edip alanyazındaki boşluğu doldurmada değerlidir. Bu bilgiler 1şığında, bu çalışmanın amacı kimlik gelişim boyutlarının ve sosyal görünüş kaygısının ergenlerin arkadaş kalitesi düzeyini anlamlı olarak yordayıp yordamadığını incelemektir.

\section{Yöntem}

$\mathrm{Bu}$ araştırma, ilişkisel tarama modelindedir. Araştırmanın çalışma grubu 2018-2019 eğitim öğretim yılında, Niğde ilindeki Atatürk Anadolu Lisesi'nde eğitim görmekte olan ve çalışmaya gönüllülük ilkesine dayalı olarak katılmayı kabul eden 285 (163 kadın ve 122 erkek) lise öğrencisi oluşmaktadır. Öğrenciler üzerinde arkadaşlı̆̆ın etkileri ile ilgili veri toplamak amacıyla Thien, Razak ve Jamil (2012) tarafindan geliştirilen ve Akın ve diğerleri (2014) tarafindan Türkçeye uyarlanan Arkadaşlık Kalitesi Ölçeği uygulanmıştır. Öğrencilerin sosyal görünüş kaygı düzeylerini tespit etmek amacıyla Hart ve arkadaşları (2008) tarafından geliştirilen ve Doğan 
(2010) tarafından Türkçeye uyarlanan Sosyal Görünüş Kaygısı Ölçeği uygulanmıștır. Kimlik gelişim süreçlerini belirlemek amaciyla Crocetti ve diğerleri (2008) tarafindan geliştirilen ve Morsünbül ve diğerleri (2014) tarafından Türkçeye uyarlanan Utrecht Kimlik Bağlanma Ölçeği kullanılmıştır.

\section{Bulgular}

Araştırma bulgularında; arkadaş kalitesi değişkenin sosyal görünüş kaygısı $(r=-.20, p<.01)$ ile negatif yönde, bağlanma yapma $(r=.39, \mathrm{p}<.01)$, derinlemesine keşif $(\mathrm{r}=.24, \mathrm{p}<.01)$ değişkenleri ile ise pozitif yönde anlamlı ilişki içinde olduğu görülmüş̧ür. Ayrıca, arkadaş kalitesi ile bağlanmanın yeniden gözden geçirilmesi arasında anlamlı bir ilişki yoktur $(r=.09, p>.05)$. Regresyon analizi sonuçlarına bakıldığında bağımsız değişkenlerin $(\mathrm{R}=.45, \mathrm{R} 2=.20, \mathrm{~F}=17.956$, $\mathrm{p}<.01)$ arkadaş kalitesini anlamlı düzeyde açıkladığı görülmektedir. Bağımsız değişkenlere ilişkin $\mathrm{t}$ testi sonuçlarına göre sosyal görünüş kaygısı $(\beta=-.20, \mathrm{p}<.01)$ ve bağlanma yapma $(\beta=.36, \mathrm{p}<.01)$ arkadaş kalitesini anlamlı olarak yordamaktadır.

\section{Tartışma ve Sonuç}

$\mathrm{Bu}$ çalışmada kimlik gelişim boyutlarının ve sosyal görünüş kaygısının ergenlerin arkadaşlık kalitesi düzeyini anlamlı olarak yordayıp yordamadığ incelenmiştir. Araştırma bulgusu arkadaşlık kalitesinin sosyal görünüş kaygısı ile negatif, bağlanma yapma ve derinlemesine keşif değişkenleri ile ise pozitif olarak ilişki içinde olduğunu göstermiştir. Ayrıca sonuçlar, kimlik boyutlarından bağlanma yapma ile sosyal görünüş kaygısının arkadaşlık kalitesi düzeyini anlamlı olarak yordadığını göstermiştir. Ergenlik döneminde sosyal görünüş büyük öneme sahiptir. Birey bu dönemde çevrenin de etkisiyle bedeni hakkında yapılan değerlendirmelere karşı daha fazla duyarlı olmakta ve olumsuz değerlendirilme endişesi taşımaktadır (Doğan, 2011). Sosyal görünüşünden hoşnut olan bireylerin özgüven, hoşgörü, arkadaşlık doyumu gibi özellikleri daha fazla taşıdığı görülmüştür (Seki ve Dilmaç, 2015). Bağlanma yapma bireyin farklı gelişim alanları ile ilgili seçimlerini kalıcı hâle getirmesi olarak tanımlanır (Morsünbül ve Uçar, 2017). Seçimlerini kalıcı hâle getiren birey daha sağlıklı bir kimlik duygusu geliştirir. Böylece birey daha yüksek benlik saygısına sahip olur, kendini daha enerjik hisseder. Çevresini ve kendisini tehdit unsuru olarak görmediği için arkadaşlık kalitesi de artar (Ryan ve Frederick, 1997). Ergenlerin olumlu beden imajına sahip olabilmeleri için benlik saygılarını arttıran psiko-eğitsel çalışmalara, sağlıklı beslenme ve spor alışkanlığının kazandırılmasına yönelik çalışmalara yer verilebilir. Ayrıca sosyal görünüş kaygısının getirmiş olduğu düşük özgüven, yalnızlık ve içe kapanma davranışlarının azaltılması, aynı zamanda sağlıklı kimlik duygusu geliştirmeleri için sınıf rehber öğretmenleri, okul psikolojik danışmanları ve uzmanlar çalışmalar yapabilir. 